\title{
Impact of a polyunsaturated fatty acid supplement on enriching the nutritional value of brine shrimp nauplii, Artemia sp.
}

\author{
Maja Prusińska, Oleksii Khudyi, Ryszard Kolman, Lidiia Khuda, Arkadiusz Duda, \\ Grzegorz Wiszniewski, Mykhailo Marchenko, Olga Kushniryk
}

Received - 06 February 2017/Accepted - 18 June 2018. Published online: 30 September 2018; @Inland Fisheries Institute in Olsztyn, Poland Citation: Prusińska M., Khudyi O., Kolman R., Khuda L., Duda A., Wiszniewski G., Marchenko M., Kushniryk O. 2018 - Impact of a polyunsaturated fatty acid supplement on enriching the nutritional value of brine shrimp nauplii, Artemia sp. - Fish. Aquat. Life 26: 173-184.

\begin{abstract}
The first aim of the study was to determine the impact the commercial product S.presso (INVE Aquaculture, Belgium) had on enriching the proximate composition of brine shrimp (Artemia sp.). The second aim of the study was to develop a better enrichment protocol for preparing enriched brine shrimp larvae. Two different enrichment protocols were investigated; the supplement was administered in either one $\left(0.5 \mathrm{~g} \mathrm{~L}^{-1}\right)$ or two equal $\left(0.25 \mathrm{~g} \mathrm{~L}^{-1}\right)$ doses. Using S.presso to enrich brine shrimp nauplii with polyunsaturated fatty acids resulted in higher levels of total lipids and higher quantities of docosahexaenoic acid DHA and eicosapentaenoic acid EPA deposition. Additionally, the enrichment supplement did not lead to overall lowered protein content values caused by increased hydrolytic activity that likely facilitates digestion in larval fish as they shift to exogenous feeding.
\end{abstract}

Keywords: Artemia, bioencapsulation, enrichment, live feed, PUFA

\footnotetext{
M. Prusińska [ ఏ], R. Kolman, A. Duda, G. Wiszniewski Department of Ichthyology, Hydrobiology and Aquatic Ecology Inland Fisheries Institute ul. Oczapowskiego 10, 10-719, Olsztyn-Kortowo, Poland e-mail:m.prusinska@infish.com.pl

O. Khudyi, L. Khuda, M. Marchenko, O. Kushniryk

Yuriy Fedkovych Chernivtsi National University Department of Biochemistry and Biotechnology Kotsubinsky Str. 2, Chernivtsi, 58012, Ukraine
}

\section{Introduction}

Laval brine shrimp (Artemia sp.) is one of the most frequently used first live foods in both industrial and amateur fish larviculture. Reduced mortality and increased growth rates are observed among many fish species when natural feeds are used during larval rearing (Akbary et al. 2010, Demény et al. 2012). Artemia sp. is a relatively safe nutritional resource for very young fish that derive from this feed not only the nutritional components required for growth and development but also a range of enzymes that they are not yet able to synthesize effectively in sufficient quantities (Léger et al. 1986). Another important aspect supporting the use of brine shrimp is the ease with which this type of feed is prepared in any given quantity and at any time as required by rearing (Bengtson et al. 1991).

Despite the many advantages of Artemia sp. nauplii, the one distinct disadvantage is that it is a nutritionally incomplete food because of the near total lack of polyunsaturated fatty acids (PUFA) $\omega-3$ such as docosahexaenoic acid (DHA) and eicosapentaenoic acid (EPA) (Navarro and Sargent 1992). These acids are formed during the desaturation and elongation of $\alpha$-linolenic acid (C18:3) (Sargent et al. 1995); however, since fish are not capable yet of independent synthesis (Henderson 1996, Tocher 2003), these must be 
delivered externally with the food. Simultaneously, polyunsaturated fatty acids are one of the most important biologically active substances. They are not only the lipid building blocks of cell membranes, but they also participate in a range of important metabolic transformations that produce eicosanoids, including prostaglandins, prostacyclin, thromboxanes, and leukotrienes (Hrytsyniak et al. 2009) and along with DHA, EPA is involved in cholesterol transport and metabolism (Kim et al. 2002).

Lipid polyunsaturated fatty acids profiles depend significantly on the type and quantity of feed consumed, which is why enriching early feed permits balancing this profile. Feeding larval fish brine shrimp nauplii enriched with PUFA is advantageous for fish growth and development, while it simultaneously lowers mortality (Akbary et al. 2010, Prusińska et al. 2011, Chepurkina et. al. 2014), decreases the number of skeletal anomalies (Cahu et al. 2003, Lall and Lewis-McCrea 2007), positively impacts digestive tract development (Kamaszewski et al. 2014a) and enzymatic activity (Kolman et al. 2018, Kamaszewski et al. 2014b), and increases resistance to stress (Adloo et al. 2012). During the process of bioencapsulation, it is important not only to choose the optimal supplement, but also to determine the appropriate enrichment procedure, i.e., the number of doses and the time regime, otherwise the supplement the brine shrimp consume will be digested. The first aim of this study was to determine the actual effects of using S.presso, and, thus, to what degree it changed the composition of the brine shrimp larvae. The second aim was to determine the optimal S.presso protocol that permits taking best advantage of the supplement while preparing enriched brine shrimp larvae.

\section{Materials and methods}

\section{Obtaining Artemia nauplii and their enrichment}

Artemia sp. cysts (20 g; Ocean Nutrition, Belgium) were incubated in $8 \mathrm{~L}$ Weiss apparatuses for $24 \mathrm{~h}$ under constant illumination and aeration at a water temperature of $28^{\circ} \mathrm{C}$. The salinity of the incubation environment was obtained by adding $\mathrm{NaCl}$ in quantities of $20 \mathrm{~g} \mathrm{~L}^{-1}$. After $24 \mathrm{~h}$ of incubation, the nauplii were separated from the cyst capsules and unhatched cysts and were transferred into Weiss apparatuses with fresh media, where enrichment was performed. For the enrichment procedure, the freshly hatched brine shrimp larvae were transferred to enrichment apparatuses at a density of 100 to 300 nauplii $\mathrm{ml}^{-1}$. The brine shrimp were enriched with S.presso, a comprehensive polyunsaturated fatty acid enrichment supplement manufactured by INVE

Table 1

The nutritional value of Artemia nauplii during starvation (control group) and with the different S.presso enrichment protocols $($ mean $\pm \mathrm{SE}, \mathrm{n}=3)$

\begin{tabular}{|c|c|c|c|c|c|c|c|c|c|}
\hline & Artemia & Control grour & & & Group I & & & Group II & \\
\hline & $0 \mathrm{~h}$ & $6 \mathrm{~h}$ & $12 \mathrm{~h}$ & $24 \mathrm{~h}$ & $6 \mathrm{~h}$ & $12 \mathrm{~h}$ & $24 \mathrm{~h}$ & $6 \mathrm{~h}$ & $12 \mathrm{~h}$ \\
\hline $\begin{array}{l}\text { Total } \\
\text { proteins } \\
\left(\mathrm{mg} \mathrm{g}^{-1} \mathrm{dwt}\right)\end{array}$ & $556.0 \pm 52.37$ & $371.5 \pm 38.30$ & $357.0 \pm 33.55$ & $337.1 \pm 34.46$ & $286.0 \pm 23.77^{*}$ & $318.2 \pm 32.55^{*}$ & $442.8 \pm 43.08^{*}$ & $285.8 \pm 27.71^{*}$ & $657.1 \pm 23.35^{*}$ \\
\hline $\begin{array}{l}\text { Total lipids } \\
\left.\text { (mg g g }{ }^{-1} \mathrm{dwt}\right)\end{array}$ & $167.7 \pm 5.55$ & $137.5 \pm 16.02$ & $169.6 \pm 29.50$ & $111.8 \pm 10.09$ & $177.5 \pm 19.27$ & $123.5 \pm 7.44^{*}$ & $167.4 \pm 21.70$ & $285.0 \pm 47.72 *$ & $259.7 \pm 18.54^{*}$ \\
\hline $\begin{array}{l}\text { Total } \\
\text { carotenoids } \\
\left(\mathrm{mg} \mathrm{g}^{-1} \mathrm{dwt}\right)\end{array}$ & $0.18 \pm 0.004$ & $0.02 \pm 0.002$ & $0.05 \pm 0.005$ & $0.04 \pm 0.005$ & $0.05 \pm 0.002^{*}$ & $0.07 \pm 0.007^{*}$ & $0.06 \pm 0.001^{*}$ & $0.02 \pm 0.003$ & $0.02 \pm 0.001^{*}$ \\
\hline
\end{tabular}

* differences among control and experimental groups are statistically significant at $\mathrm{P} \leq 0.05$ 
Aquaculture (Belgium) that is formulated with dried algae and fish oil.

Artemia were enriched with different protocols, which is why two experimental groups and one control group were created:

- experimental group I - a daily dose of $0.5 \mathrm{~g} \mathrm{~L}^{-1}$ was added in one portion at the beginning of Artemia nauplii cultivation ( $0 \mathrm{~h})$;

- experimental group II - a daily dose was added in two equal portions of $0.25 \mathrm{~g} \mathrm{~L}^{-1}$ each at the beginning of incubation and after $6 \mathrm{~h}$.

Artemia nauplii that did not receive S.presso, but which were cultivated under the same conditions as the experimental groups, served as the control. There were three replicates of each group. Samples of nauplii were collected at the beginning of the enrichment process $(0 \mathrm{~h})$ and also after 6,12 , and $24 \mathrm{~h}$. We also decided to collect samples from one group after $24 \mathrm{~h}$ of the enrichment period.

\section{Biochemical analysis}

The samples selected for the study were dried on filter paper and then weighed on a Precisa 120A analytical scale ( $\pm 1 \mathrm{mg}$ ) and frozen in liquid nitrogen. Analyses of all biochemical parameters were conducted in six replicates. The contents of fatty and amino acids and mineral composition were determined in three replicates.

All calculations were performed on dry weights. The samples were dried at $60^{\circ} \mathrm{C}$ for $24 \mathrm{~h}$ until they reached a constant weight (Postel et al. 2000). Sample ash content was determined following combustion in a muffle furnace at $550^{\circ} \mathrm{C}$ for $8 \mathrm{~h}$ (ISO 2002). $\mathrm{Ca}^{2+}, \mathrm{Na}^{+}, \mathrm{K}^{+}, \mathrm{Fe}^{2+/ 3+}, \mathrm{Ni}^{2+}, \mathrm{Cu}^{2+}$, and $\mathrm{Zn}^{2+}$ content in the ash was determined with an atomic absorption spectrophotometer C-115-M1 using appropriate standards.

Samples weighing 1-1.5 g were homogenized at $+4^{\circ} \mathrm{C}$ in a Potter-Elvehjem homogenizer using a phosphate buffer with a $\mathrm{pH}$ of 7.4 . The homogenate was centrifuged at $15000 \mathrm{~g}$ for $15 \mathrm{~min}$. Lipid extraction was performed with the Folch method (Folch et al. 1957). Total lipids were determined with acid hydrolysis followed by the reaction between the decomposition products and phospho-vanillin reagent (Knight et al. 1972). The total carotenoid content of the samples was determined by spectrophotometry at $\lambda 450 \mathrm{~nm}$ after deposition with Carrez solution I and Carrez solution II, acetone extraction, and subsequent purification with petroleum ether (GOST R 54058-2010 2011).

Lipase activity was determined with the standardized method (Sklyarov et al. 2008). Proteolytic activity was investigated with the modified Anson's method (GOST 20264.2-88 1988). Enzyme activity was expressed in conventional units per mg protein, where 1 unit (U) corresponds to that amount of enzyme that catalyzes the conversion of 1 micromole of substrate in $1 \mathrm{~m}$. The activity of $\alpha$-amylase was determined with the Caraway amylolytic method (Caraway 1959) and expressed as mg of starch converted by the enzyme in $1 \mathrm{~h}$ calculated per mg of protein. The total protein content was determined with Lowry's method (Lowry et al. 1951).

Amino acid content was determined with ion-exchange liquid-column chromatography on a $\mathrm{T}$ 339 automatic amino acid analyzer (Prague, Czech Republic). The amino acids in the eluate were registered with the ninhydrin detection method (Kozarenko 1975). The qualitative composition of the amino acid mixture was determined by comparing the chromatograms of standard and test amino acid mixtures. The contents of individual amino acids were expressed as percentages of total amino acid weight. Amino acid tryptophan was not determined. Asn and Gln content was assayed with Asp and Glu, respectively.

Fatty acids were determined with gas chromatography on an HRGC 5300 chromatograph (Italy) in a $3.5 \mathrm{~m}$ glass column filled with Chromosorb W / HP with the application of a $10 \%$ liquid phase of Silar $5 \mathrm{CP}$ at a programmed temperature of $140-250^{\circ} \mathrm{C}$ (Kates 1973, Baidalinova et al. 1977). The identification of individual fatty acids was conducted using the respective standards by Sigma; their contents were expressed as the percentage of the total amount of fatty acids. 
All the data are presented as mean \pm SE. Mean values were considered significantly different at $\mathrm{P}<$ 0.05. The significance of differences in the results was evaluated with one-way ANOVA. Statistical analysis was computed using MS Excel software and STATISTICA 6.0.

\section{Results}

The analysis of brine shrimp nutrient values at 6,12 , and $24 \mathrm{~h}$ of the experiment indicated there were significant decreases in total protein content in group I and the control group (Table 1). Generally, a progressive increase in total protein was noted in both experimental groups (I and II), while in the unenriched control groups this value decreased progressively over time.
Total lipid analysis indicated that there was significant increase in experimental group II (two doses of S.presso of $0.25 \mathrm{~g} \mathrm{~L}^{-1}$ at $6 \mathrm{~h}$ intervals). However, a single dose of S. presso resulted in only a slight increase in total lipid content during the $6 \mathrm{~h}$ following the beginning of the experiment. However, carotenoid content in all the groups studied decreased in comparison to initial values.

Since enriching brine shrimp with S.presso with the two-stage protocol resulted in increased protein and lipid contents, the dynamics of amino and fatty acids compositions were only examined in experimental group II, which is the group in which $S$. presso was administered in two doses (Tables 2-3). Enriching brine shrimp nauplii with S.presso resulted in significant increases in the content of some amino acids (Asp+Asn and Glu+Gln), while decreases were observed in the percentages of others (His, Arg, and Pro). However, when the corresponding parameters were compared with the brine shrimp

Table 2

Amino acids profile of Artemia sp. nauplii during S.presso enrichment (mean \pm SE, $n=3$ )

\begin{tabular}{|c|c|c|c|c|}
\hline \multirow[b]{2}{*}{ Amino acids } & \multirow[b]{2}{*}{ S.presso } & \multirow{2}{*}{$\frac{\text { Artemia }}{0 \mathrm{~h}}$} & \multicolumn{2}{|c|}{ Artemia from group II } \\
\hline & & & $6 \mathrm{~h}$ & $12 \mathrm{~h}$ \\
\hline Lys & $4.96 \pm 0.246$ & $9.24 \pm 0.832$ & $8.59 \pm 0.727$ & $9.49 \pm 0.817$ \\
\hline His & $1.40 \pm 0.075$ & $3.11 \pm 0.256$ & $2.66 \pm 0.231$ & $2.62 \pm 0.217$ \\
\hline Arg & $11.86 \pm 0.719$ & $7.60 \pm 0.874$ & $6.89 \pm 0.499$ & $6.53 \pm 0.680$ \\
\hline Asp + Asn & $11.08 \pm 0.609$ & $9.63 \pm 0.721$ & $1.12 \pm 0.920$ & $1.92 \pm 0.943$ \\
\hline Thr & $4.77 \pm 0.226$ & $5.26 \pm 0.490$ & $5.08 \pm 0.498$ & $5.16 \pm 0.461$ \\
\hline Ser & $5.81 \pm 0.354$ & $6.51 \pm 0.634$ & $6.58 \pm 0.611$ & $6.37 \pm 0.542$ \\
\hline Glu + Gln & $28.35 \pm 1.583$ & $16.49 \pm 1.334$ & $16.30 \pm 1.458$ & $18.38 \pm 1.797$ \\
\hline Pro & $0.38 \pm 0.023$ & $4.02 \pm 0.321^{\mathrm{a}}$ & $5.79 \pm 0.461^{b}$ & $2.59 \pm 0.299^{c}$ \\
\hline Gly & $7.02 \pm 0.450$ & $6.40 \pm 0.693$ & $5.78 \pm 0.480$ & $6.15 \pm 0.539$ \\
\hline Ala & $6.09 \pm 0.323$ & $6.08 \pm 0.586$ & $5.98 \pm 0.646$ & $6.11 \pm 0.547$ \\
\hline Cys & $1.07 \pm 0.049$ & $1.05 \pm 0.107$ & $0.87 \pm 0.071$ & $0.90 \pm 0.070$ \\
\hline Val & $3.36 \pm 0.189$ & $3.19 \pm 0.273$ & $3.85 \pm 0.316$ & $3.29 \pm 0.382$ \\
\hline Met & $1.12 \pm 0.076$ & $2.71 \pm 0.259$ & $2.41 \pm 0.188$ & $2.33 \pm 0.248$ \\
\hline Ile & $2.31 \pm 0.142$ & $2.40 \pm 0.225$ & $3.07 \pm 0.299$ & $2.77 \pm 0.243$ \\
\hline Leu & $4.80 \pm 0.247$ & $6.93 \pm 0.556$ & $7.05 \pm 0.528$ & $6.94 \pm 0.556$ \\
\hline Tyr & $2.84 \pm 0.165$ & $4.67 \pm 0.506$ & $4.50 \pm 0.458$ & $4.58 \pm 0.397$ \\
\hline Phe & $2.77 \pm 0.180$ & $4.69 \pm 0.535$ & $4.48 \pm 0.431$ & $4.89 \pm 0.570$ \\
\hline
\end{tabular}

Values in the same row with different letter indexes differ significantly statistically at a level of significance $(\mathrm{P}<0.05)$ 
Table 3

Fatty acids profile of Artemia sp. nauplii during S.presso enrichment (mean \pm SE, $n=3$ )

\begin{tabular}{|c|c|c|c|c|c|}
\hline \multirow[b]{3}{*}{ Fatty acids } & & \multicolumn{4}{|c|}{ Share of total fatty acids (\%) } \\
\hline & & \multirow[b]{2}{*}{ S.presso } & \multirow{2}{*}{$\frac{\text { Artemia }}{0 \mathrm{~h}}$} & \multicolumn{2}{|c|}{ Artemia from group II } \\
\hline & & & & $6 \mathrm{~h}$ & $12 \mathrm{~h}$ \\
\hline Caproic & C6:0 & $0.215 \pm 0.0096$ & - & $1.142 \pm 0.0974$ & $1.399 \pm 0.1043$ \\
\hline Enanthic & $\mathrm{C} 7: 0$ & - & - & $0.024 \pm 0.0022^{\mathrm{a}}$ & $0.052 \pm 0.0045^{\mathrm{b}}$ \\
\hline Caprylic & $\mathrm{C} 8: 0$ & $0.384 \pm 0.0147$ & $0.161 \pm 0.0160^{\mathrm{a}}$ & $1.553 \pm 0.1561^{\mathrm{b}}$ & $3.698 \pm 0.3369^{c}$ \\
\hline Pelargonic & C9:0 & $0.104 \pm 0.0066$ & $0.014 \pm 0.0015$ & - & - \\
\hline Caprinic & C10:0 & $0.007 \pm 0.0003$ & $0.012 \pm 0.0011^{\mathrm{a}}$ & $0.092 \pm 0.0066^{\mathrm{b}}$ & $0.179 \pm 0.0142^{\mathrm{c}}$ \\
\hline Undecanoic & C11:0 & $0.008 \pm 0.0005$ & $0.016 \pm 0.0015^{\mathrm{a}}$ & $0.161 \pm 0.0144^{\mathrm{b}}$ & $0.323 \pm 0.0263^{\mathrm{c}}$ \\
\hline Isolauric & Ci12:0 & - & $0.027 \pm 0.0028^{\mathrm{a}}$ & $0.109 \pm 0.0115^{\mathrm{b}}$ & $0.179 \pm 0.0181^{\mathrm{c}}$ \\
\hline Lauric & $\mathrm{C} 12: 0$ & $0.020 \pm 0.0010$ & $0.044 \pm 0.0051$ & $0.037 \pm 0.0031$ & $0.029 \pm 0.0021$ \\
\hline Tridecylic & C13:0 & - & - & $0.057 \pm 0.0051^{\mathrm{a}}$ & $0.080 \pm 0.0064^{b}$ \\
\hline Isomyristic & Ci14:0 & - & $0.071 \pm 0.0060^{\mathrm{a}}$ & $0.145 \pm 0.0153^{\mathrm{b}}$ & $0.234 \pm 0.0227^{\mathrm{c}}$ \\
\hline Myristic & $\mathrm{C} 14: 0$ & $0.632 \pm 0.0236$ & $0.629 \pm 0.0582$ & $0.716 \pm 0.0660$ & $0.573 \pm 0.0421$ \\
\hline Pentadecanoic & $\mathrm{C} 15: 0$ & $0.032 \pm 0.0021$ & $0.112 \pm 0.0131$ & $0.097 \pm 0.0075$ & $0.082 \pm 0.0070$ \\
\hline Isopalmitic & Ci16:0 & - & $0.511 \pm 0.0505$ & $0.659 \pm 0.0670$ & $0.724 \pm 0.0851$ \\
\hline Palmitic & $\mathrm{C} 16: 0$ & $13.680 \pm 0.4797$ & $11.484 \pm 1.3346$ & $11.090 \pm 1.0951$ & $10.190 \pm 0.9882$ \\
\hline Margaric & $\mathrm{C} 17: 0$ & $0.036 \pm 0.0021$ & $0.655 \pm 0.0699$ & $0.667 \pm 0.0638$ & $0.690 \pm 0.0503$ \\
\hline Isostearic & Ci18:0 & - & $0.791 \pm 0.0888$ & $0.810 \pm 0.0803$ & $0.677 \pm 0.0812$ \\
\hline Stearic & C18:0 & $0.829 \pm 0.0257$ & $3.902 \pm 0.4148$ & $3.467 \pm 0.2529$ & $3.632 \pm 0.3620$ \\
\hline Arachidic & C20:0 & $0.542 \pm 0.0313$ & $5.137 \pm 0.4910$ & $5.218 \pm 0.4684$ & $5.038 \pm 0.4512$ \\
\hline Heneicosylic & $\mathrm{C} 21: 0$ & $0.187 \pm 0.0057$ & $0.120 \pm 0.0101^{\mathrm{a}}$ & $0.229 \pm 0.0227^{b}$ & $0.915 \pm 0.0657^{\mathrm{c}}$ \\
\hline Behenic & $\mathrm{C} 22: 0$ & - & $0.697 \pm 0.0743$ & $0.642 \pm 0.0649$ & $0.784 \pm 0.0695$ \\
\hline$\Sigma$ SFA & & 16.676 & 24.383 & 26.915 & 29.478 \\
\hline Lauricoleic & $\mathrm{C} 12: 1$ & - & $0.034 \pm 0.0026^{\mathrm{a}}$ & $0.095 \pm 0.0091^{b}$ & $0.133 \pm 0.0122^{\mathrm{c}}$ \\
\hline Myristoleic & $\mathrm{C} 14: 1$ & $0.048 \pm 0.0024$ & $0.795 \pm 0.0854$ & $0.817 \pm 0.0576$ & $0.658 \pm 0.0573$ \\
\hline Pentadecenoic & C15:1 & - & $0.080 \pm 0.0070$ & $0.100 \pm 0.0101$ & $0.075 \pm 0.0070$ \\
\hline Palmitoleic & $\mathrm{C} 16: 1$ & $0.446 \pm 0.0280$ & $3.832 \pm 0.4039$ & $3.785 \pm 0.3265$ & $3.300 \pm 0.3239$ \\
\hline Heptadecenoic & $\mathrm{C} 17: 1$ & $0.115 \pm 0.0059$ & $1.174 \pm 0.1062$ & $1.194 \pm 0.1226$ & $1.100 \pm 0.1420$ \\
\hline Oleic & C18:1 & $11.414 \pm 0.4769$ & $26.409 \pm 2.6572$ & $24.905 \pm 2.4013$ & $23.734 \pm 2.3878$ \\
\hline Gadoleic & C20:1 & $0.562 \pm 0.0350$ & $0.422 \pm 0.0435^{\mathrm{a}}$ & $0.659 \pm 0.0613^{b}$ & $1.219 \pm 0.1165^{\mathrm{c}}$ \\
\hline Erucic & $\mathrm{C} 22: 1$ & - & $1.768 \pm 0.1665$ & - & - \\
\hline$\Sigma$ MUFA & & 12.585 & 34.514 & 31.555 & 30.219 \\
\hline Tetradecadienoic & $\mathrm{C} 14: 2 \mathrm{n}-6$ & - & $0.482 \pm 0.0477$ & $0.517 \pm 0.0509$ & $0.434 \pm 0.0447$ \\
\hline Hexadecadienoic & $C 16: 2 n-6$ & - & $1.034 \pm 0.09643$ & $0.882 \pm 0.0798$ & $0.709 \pm 0.05841$ \\
\hline Linoleic & $C 18: 2 n-6$ & $8.318 \pm 0.4145$ & $6.229 \pm 0.7086$ & $6.157 \pm 0.6324$ & $5.736 \pm 0.6244$ \\
\hline Linolenic & C18:3n-3 & $1.246 \pm 0.0794$ & $30.648 \pm 3.3478$ & $29.409 \pm 3.5717$ & $27.220 \pm 2.6019$ \\
\hline Eicosadienoic & $C 20: 2 n-6$ & $0.699 \pm 0.0456$ & - & $0.147 \pm 0.0140^{\mathrm{a}}$ & $0.462 \pm 0.0476^{\mathrm{b}}$ \\
\hline Arachidonic & $C 20: 4 n-6$ & - & $1.964 \pm 0.1592$ & $1.890 \pm 0.1611$ & $2.200 \pm 0.2003$ \\
\hline
\end{tabular}


cont. Table 3

\begin{tabular}{|c|c|c|c|c|c|}
\hline \multirow[b]{3}{*}{ Fatty acids } & & \multicolumn{4}{|c|}{ Share of total fatty acids (\%) } \\
\hline & & \multirow[b]{2}{*}{ S.presso } & \multirow{2}{*}{$\frac{\text { Artemia }}{0 \mathrm{~h}}$} & \multicolumn{2}{|c|}{ Artemia from group II } \\
\hline & & & & $6 \mathrm{~h}$ & $12 \mathrm{~h}$ \\
\hline Eicosapentaenoic & $\mathrm{C} 20: 5 \mathrm{n}-3$ & $3.663 \pm 0.1686$ & - & $1.703 \pm 0.1554$ & $1.929 \pm 0.2371$ \\
\hline Docosatrienoic & $\mathrm{C} 22: 3 \mathrm{n}-3$ & $2.011 \pm 0.0560$ & - & - & - \\
\hline Docosatetraenoic & $C 22: 4 n-6$ & $0.855 \pm 0.0390$ & $0.153 \pm 0.0115$ & - & - \\
\hline Docosapentaenoic & $\mathrm{C} 22: 5 \mathrm{n}-6$ & - & - & - & $0.117 \pm 0.0104$ \\
\hline Docosahexaenoic & C22:6n-3 & $53.940 \pm 3.1644$ & $0.177 \pm 0.0144^{\mathrm{a}}$ & $0.034 \pm 0.0026^{b}$ & $0.735 \pm 0.0605^{\mathrm{c}}$ \\
\hline$\Sigma$ PUFA & & 70.732 & 40.687 & 40.739 & 39.542 \\
\hline$\Sigma \mathrm{n}-3$ & & 60.860 & 30.825 & 31.146 & 29.884 \\
\hline$\Sigma \mathrm{n}-6$ & & 9.872 & 9.862 & 9.593 & 9.658 \\
\hline$n-3 / n-6$ & & 6.16 & 3.13 & 3.25 & 3.09 \\
\hline DHA/EPA & & 14.73 & - & 0.02 & 0.38 \\
\hline
\end{tabular}

Values in the same row with different letter indexes differ significantly statistically at a level of significance $(\mathrm{P}<0.05)$

Table 4

Mineral composition ( $\mathrm{mg} \mathrm{kg}^{-1}$ ) of Artemia sp. nauplii during S.presso enrichment (mean $\pm \mathrm{SE}, \mathrm{n}=3$ )

\begin{tabular}{|c|c|c|c|c|c|c|c|c|c|}
\hline Groups & $\begin{array}{l}\text { Moisture } \\
\% \\
\end{array}$ & $\begin{array}{l}\text { Ash } \\
\% \\
\end{array}$ & $\mathrm{Ca}^{2+}$ & $\mathrm{Na}^{+}$ & $\mathrm{K}^{+}$ & $\mathrm{Fe}^{2+/ 3+}$ & $\mathrm{Zn}^{2+}$ & $\mathrm{Ni}^{2+}$ & $\mathrm{Cu}^{2+}$ \\
\hline $\begin{array}{l}\text { Artemia } \\
\text { cysts }\end{array}$ & $9.2 \pm 0.98$ & $4.0 \pm 0.23$ & $155.8 \pm 14.75$ & $2046.2 \pm 145.08$ & $4985.1 \pm 533.22$ & $227.7 \pm 14.29$ & $67.1 \pm 5.82$ & $1.0 \pm 0.09$ & $7.1 \pm 0.53$ \\
\hline $\begin{array}{l}\text { Artemia } \\
0 \mathrm{~h}\end{array}$ & $91.5 \pm 9.34$ & $7.6 \pm 0.64$ & $134.3 \pm 11.12$ & $2723.8 \pm 251.21$ & $411.2 \pm 30.82$ & $13.2 \pm 1.33$ & $15.1 \pm 1.11$ & $0.4 \pm 0.04$ & $2.6 \pm 0.26$ \\
\hline \multicolumn{10}{|l|}{ Control } \\
\hline $6 \mathrm{~h}$ & $88.7 \pm 9.12$ & $4.8 \pm 0.35$ & $156.6 \pm 16.16$ & $3293.1 \pm 215.51$ & $712.0 \pm 55.73$ & $33.8 \pm 3.31$ & $22.3 \pm 1.99$ & $0.7 \pm 0.06$ & $3.9 \pm 0.40$ \\
\hline $12 \mathrm{~h}$ & $89.0 \pm 8.81$ & $7.9 \pm 0.72$ & $108.3 \pm 8.94$ & $3624.4 \pm 261.96$ & $582.7 \pm 40.81$ & $19.6 \pm 2.08$ & $15.9 \pm 1.83$ & $0.4 \pm 0.03$ & $3.2 \pm 0.32$ \\
\hline $24 \mathrm{~h}$ & $88.6 \pm 9.03$ & $12.9 \pm 1.37$ & $160.8 \pm 12.27$ & $6206.2 \pm 517.56$ & $948.8 \pm 76.80$ & $17.6 \pm 1.33$ & $29.1 \pm 2.09$ & $1.8 \pm 0.15$ & $2.2 \pm 0.20$ \\
\hline \multicolumn{10}{|l|}{ Group I } \\
\hline $6 \mathrm{~h}$ & $86.7 \pm 8.94$ & $15.7 \pm 1.50^{*}$ & $144.2 \pm 12.80$ & $9015.6 \pm 970.99 *$ & $922.2 \pm 91.49 *$ & $17.6 \pm 1.35^{*}$ & $22.0 \pm 1.76$ & $0.7 \pm 0.07$ & $2.4 \pm 0.23^{*}$ \\
\hline $12 \mathrm{~h}$ & $88.6 \pm 8.73$ & $15.3 \pm 1.35^{*}$ & $127.1 \pm 13.16$ & $6967.3 \pm 653.29^{*}$ & $859.2 \pm 69.89^{*}$ & $16.2 \pm 1.70$ & $28.6 \pm 2.04^{*}$ & $1.1 \pm 0.10^{*}$ & $4.4 \pm 0.35^{*}$ \\
\hline $24 \mathrm{~h}$ & $90.9 \pm 9.28$ & $7.0 \pm 0.76^{*}$ & $134.6 \pm 11.26^{*}$ & $2693.0 \pm 229.27^{*}$ & $712.1 \pm 51.05^{*}$ & $21.7 \pm 2.08$ & $27.8 \pm 2.10$ & $0.7 \pm 0.06^{*}$ & $2.5 \pm 0.20$ \\
\hline \multicolumn{10}{|l|}{ Group II } \\
\hline $6 \mathrm{~h}$ & $86.4 \pm 9.01$ & $10.0 \pm 0.81^{*}$ & $158.7 \pm 13.13$ & $13739.5 \pm 1103.90^{*}$ & $1512.6 \pm 113.09 *$ & $23.6 \pm 2.14^{*}$ & $20.0 \pm 2.01$ & $0.7 \pm 0.08$ & $4.6 \pm 0.45$ \\
\hline $12 \mathrm{~h}$ & $88.4 \pm 8.74$ & $5.6 \pm 0.55^{*}$ & $135.9 \pm 14.35^{*}$ & $3769.8 \pm 401.89$ & $727.7 \pm 64.42^{*}$ & $15.4 \pm 1.55$ & $21.0 \pm 1.85^{*}$ & $0.5 \pm 0.05$ & $2.3 \pm 0.20^{*}$ \\
\hline
\end{tabular}

*differences among control and experimental groups are statistically significant at $\mathrm{P}<0.05$

prior to enrichment, increases in the overall protein content in the brine shrimp were noted.

The analysis of the brine shrimp fatty acids in comparison to the fatty acids in S.presso indicated that of the 25 fatty acids in the latter, four were not detected in the brine shrimp. Following enrichment, the composition of the brine shrimp increased considerably with as many as 35 fatty acids being 
identified, of which nearly 56\% were SFA, 20\% were MUFA, and 24\% were PUFA. Prior to enrichment, the analysis of brine shrimp proximate composition identified 32 FA, while after 12 h, 35 FA were identified (Table 3).

Determinations of the fatty acids profiles of brine shrimp indicated higher values of some PUFAs from both the $n-3$ and n- 6 families in both variants of the experiment (groups I and II), but not in the control group. No substantial changes were noted in the overall contents of $n-3$ or $n-6$ PUFA or in the relative mutual proportions of these in the brine shrimp
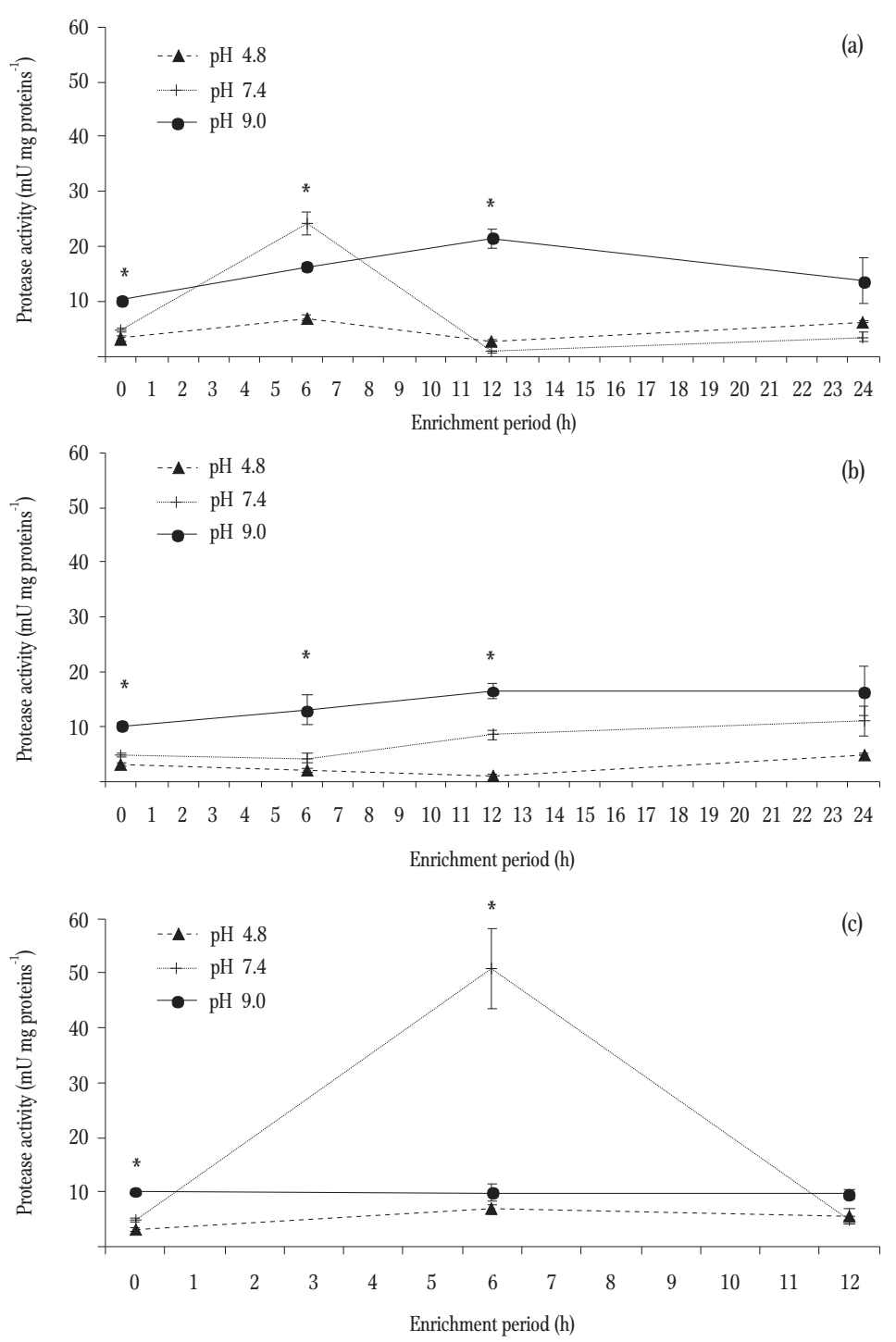

Figure 1. Total protease activity at different $\mathrm{pH}$ in Artemia sp. nauplii (a - control group, b - I experimental group, c - II experimental group). * differences among groups are statistically significant at $\mathrm{P}<0.05$. nauplii during the application of the enrichment protocols.

The characteristics of the brine shrimp ash mineral composition showed significant differences in the content of ions $\mathrm{K}^{+}$and $\mathrm{Fe}^{2+/ 3+}$ between the cysts and the nauplii (Table 4). The contents of other elements at key developmental stages did not fluctuate significantly.

The analysis of the enzymatic activity of brine shrimp nauplii indicated increased acidic, neutral, and alkaline protease activity in the control group at 6 h (Fig. 1a), but the degree of acidic protease activity throughout the experiment did not fluctuate significantly. The study of proteolytic activity in the nauplii from experimental group I indicated a lack of significant differences in protease activity at all of the $\mathrm{pH}$ levels studied (Fig. 1b). The analysis of protease activity in brine shrimp nauplii from experimental group II indicated there was increased activity in the hydrolytic enzymes at a neutral $\mathrm{pH}$ at $6 \mathrm{~h}$. This increase was almost ten-fold, while acidic and alkaline protease activity throughout the experiment remained constant (Fig. 1c).

The analysis of $\alpha$-amylase activity in brine shrimp nauplii indicated that it increased throughout the experiment in both experimental groups (I and II) and also in the control group (Fig. 2a). Throughout the experiment, increased lipase activity was also noted in both the control group and experimental group II, with higher values noted in the latter. However, one-stage brine shrimp enrichment resulted in lowered lipase activity (Fig. 2b).

\section{Discussion}

\section{Impact of S.presso on the proximate composition of brine shrimp nauplii}

The analysis of brine shrimp nutritional composition indicated decreased total lipid values throughout the duration of the experiment among starving nauplii from the 

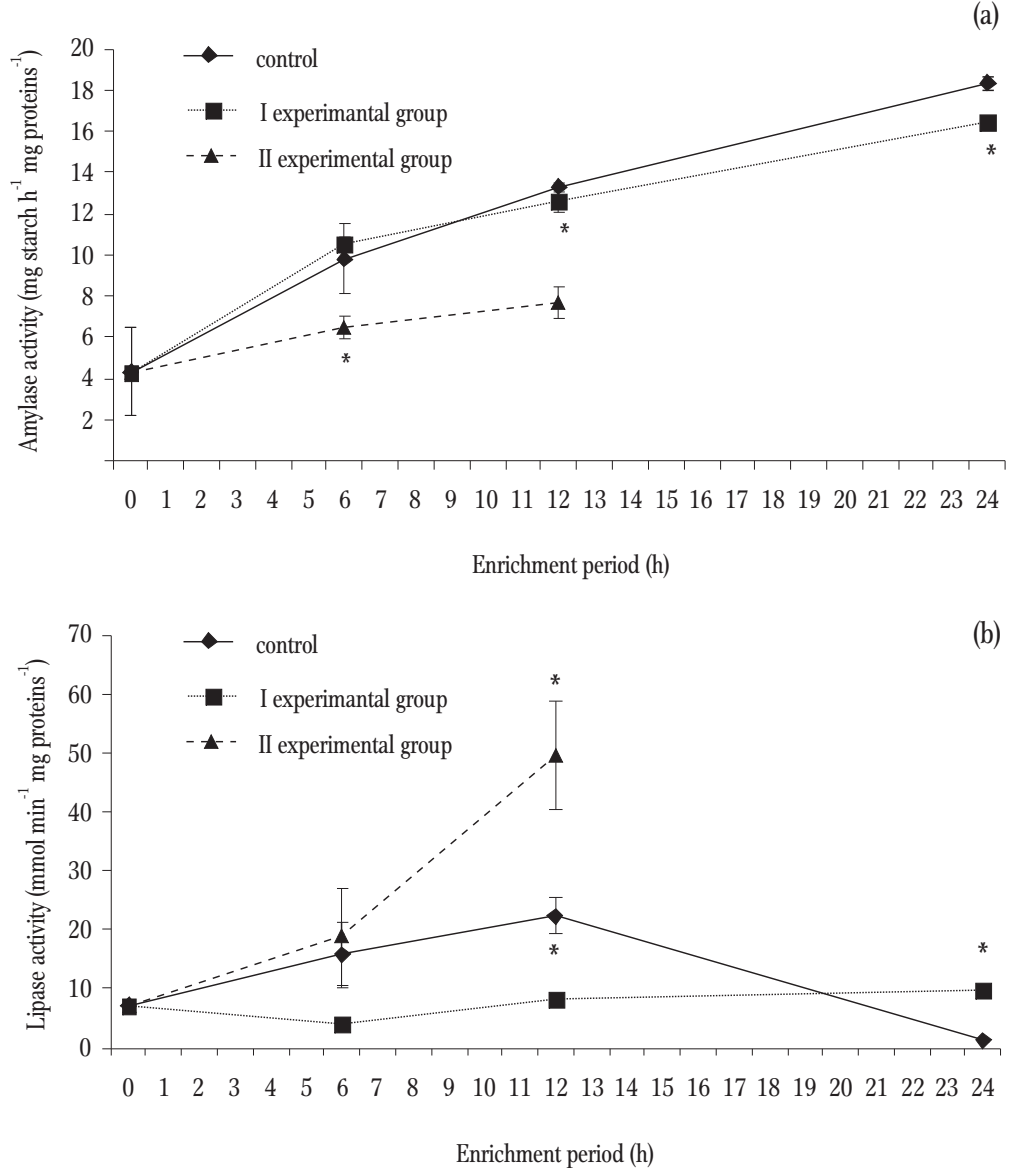

Figure 2. $\alpha$-amylase (a) and lipase (b) activities in Artemia sp. nauplii during enrichment period. *differences among groups are statistically significant at $\mathrm{P}<0.05$.

control group that stemmed from the use of energy stores in the cysts (García-Ortega et al. 1998, Monroig et al. 2006). In contrast to the starving control group, higher total lipid values were observed in the brine shrimp nauplii from both of the experimental groups (I and II), which was the direct result of the assimilation of the fatty acids in S.presso and indicates that bioencapsulation was successful. The tendency of increasing fatty acid content in crustaceans is also observed through their enrichment with other sources of fatty acids (Hafezieh et al. 2009, Najdegerami et al. 2015). ANOVA analysis of variance indicated statistically significantly differences in the fatty acids content of the brine shrimp nauplii from all the groups investigated.

The most rapid decrease in protein content among brine shrimp was noted immediately after hatching, which was most likely linked to the discarding of the chorion (García-Ortega et al. 1998). The next decrease in total protein content at $6 \mathrm{~h}$ in all groups could be explained by the catabolism of reserves (Aragăo et al. 2004). Since S.presso contains a low percentage of protein and the main component is lipids, brine shrimp nauplii that are enriched with it later shift to using the lipid substrate in the emulsion as energy. Because of this, the nauplii no longer use proteins as energy, which permits all of (b) the amino acids in S.presso to be used for de novo protein synthesis. The increased glutamic acid content of the nauplii enriched with S.presso can be explained by its active participation in the processes of transamination, which ensures that the brine shrimp nauplii have the necessary quantities of essential amino acids. Additionally, S.presso is a source of all non-essential amino acids, thanks to which bioencapsulation with the product studied permitted the brine shrimp to meet their protein synthesis needs.

During the experiment, the carotenoid content of the proximate composition of the brine shrimp nauplii decreased successively, which most probably stemmed from the fact that the level depends on crustacean developmental stage, and it decreases with development. This is linked, inter alia, with decreasing levels of the xanthophils astaxanthin and canthaxanthin (Nelis et al. 1988).

The analysis of the fatty acids in S.presso indicated that the proportion of DHA/EPA was nearly $15: 1$, which was 1.6 times higher than the proportion of 9:1 declared on the manufacturer's packaging. The decreased EPA content noted in S.presso was likely linked, inter alia, to how and for how long the product was stored, which has a direct impact on the fatty acid content of the emulsion (Adloo et al. 2012). The lack of EPA in the unenriched brine shrimp nauplii is noteworthy. Usually in unenriched brine shrimp nauplii either both PUFAs are present or 
DHA is lacking, but EPA is present, although it usually occurs in very low quantities (Chakraborty et al. 2007, Hafezieh et al. 2009, Nhu et al. 2009, Adloo et al. 2012). The exceptional lack of EPA in the nauplii examined is probably associated with the place of origin of the cysts or the specific season that preceded the collection of the cysts from the environment.

As mentioned previously, the two-stage S.presso enrichment protocol for brine shrimp nauplii was effective in terms of higher total lipid contents. The decreased lipid content observed after $12 \mathrm{~h}$ of the experiment could have been linked to the beginning of emulsion autoxidation and the environmental accumulation of the toxic products of fat hydroxylation (McEvoy et al. 1995, Monroig et al. 2007). This phenomenon probably influenced the lowered MUFA and n-3 PUFA contents along with increased SFA. Additionally, insignificant DHA decreases and slight EPA increases after $6 \mathrm{~h}$ of enrichment could have resulted from the ability of DHA to reconvert to EPA (Navarro et al. 1999). The degree to which DHA reconverts to EPA depends on the type of brine shrimp, the enrichment methodology applied, temperature, lighting, and other environmental factors (Vite-García et al. 2014). Taking into consideration the results obtained, it was concluded that the more effective method for enriching brine shrimp nauplii with fats and protein is the S.presso two-stage protocol of $0.25 \mathrm{~g} \mathrm{~L}^{-1}$ with a second dose in the same quantity $6 \mathrm{~h}$ after the initial dose.

\section{Impact of S.presso on brine shrimp nauplius hydrolytic activity}

The results obtained from the investigation indicate that one-stage enrichment did not stimulate the hydrolytic activity of the brine shrimp digestive enzymes; however, no significant deposition of nutrients was noted either. The daily one-stage enrichment protocol either slows down hydrolytic activity or has no impact, which is also why this enrichment protocol is considered to be ineffective. Additionally, this S.presso delivery method is known to lead to higher mortality among brine shrimp nauplii (Prusińska et al. 2015).

During two-stage enrichment with S.presso, the main role in enhancing brine shrimp nauplius proteolytic activity is played by protease with alkaline $\mathrm{pH}$ and, in some instances, neutral $\mathrm{pH}$. This phenomenon is also confirmed by literature data (García-Ortega et al. 1998). Additionally, increases in lipase activity are noted that are associated with the digestion and assimilation of the lipids in the product. Together with other enzymes in the nauplii (Dąbrowski and Glogowski 1977), brine shrimp lipase can be an exogenous factor predisposing the activity of digestive enzymes in the digestive tracts of larval fish (Gawlicka et al. 2000). They can effectively supplement deficits in the noneffective, undeveloped digestive tracts of larval fish, which facilitates the effective digestion of the first exogenous food consumed.

\section{Impact of S.presso on the mineral composition of brine shrimp nauplii}

It was confirmed that enriching brine shrimp nauplii with S.presso increased the content of some ions $\left(\mathrm{Na}^{+}, \mathrm{K}^{+}, \mathrm{Zn}^{2+}\right)$ in both experimental groups. As is widely known, the $\mathrm{Na}^{+}$and $\mathrm{K}^{+}$ions play key roles in maintaining ion balance and the functioning of cell bioelectric activity. Consequently, ensuring that start feed contains quantities of these elements that meet the requirements of the fish should positively impact the development of nerve and muscle activity in larvae during early developmental stages.

It is also known that providing larval fish brine shrimp nauplii with higher levels of $\mathrm{Zn}^{2+}$ optimizes metabolism thanks to the cofactor function of this ion in more than eighty enzymes. It has also been demonstrated that using brine shrimp nauplii enriched with zinc and manganese ensures proper skeletal development in larval fish (Nguyen et al. 2008). In effect, it was confirmed that enriching brine shrimp nauplii with S.presso also has a positive impact on their mineral content. 


\section{Conclusions}

Using S.presso to enrich brine shrimp nauplii with polyunsaturated fatty acids led to increased levels of total lipids and lacking DHA and EPA. Additionally, using the product did not cause lowered protein content, while it caused greater hydrolytic activity that facilitated the digestion of brine shrimp nauplii enriched with S.presso by fish that are shifting to exogenous feeding. Taking into consideration the results obtained, it was concluded that the more effective method for enriching brine shrimp nauplii with fats and protein is the S.presso two-stage protocol of 0.25 $\mathrm{g} \mathrm{L}^{-1}$ with a second dose in the same quantity $6 \mathrm{~h}$ after the initial dose.

Acknowledgements. This study was conducted within the framework of statutory research project S-009 at the Inland Fisheries Institute in Olsztyn (IFI) and 0117 U001155 at Yuriy Fedkovych Chernivtsi National University (CHNU) as well as within the framework of the cooperation agreement between IFI and CHNU.

Author contributions. R.K. and O.Kh. supervised the experiment, M.P. designed the experiments; M.P. and O.Ku. managed the experimental procedures; L.K. conducted the experiments on enzyme biochemistry; O.Ku. and M.M. analyzed the biochemical composition of the study subjects; A.D. and G.W. participated in the experimental process and Artemia cyst incubation; O.Kh. performed the statistical data analysis; M.P., O.Kh., O.Ku., and L.K. prepared the manuscript; M.P. and O.Kh. revised the article.

\section{References}

Adloo M.N., Matinfar A., Sourinezhad I. 2012 - Effects of feeding enriched Artemia franciscana with HUFA, vitamin $\mathrm{C}$ and $\mathrm{E}$ on growth performance, survival and stress resistance of yellowfin seabream larvae - J. Aquacult. Res. Dev. 3: 157.

Akbary P., Hosseini S.A., Imanpoor M., Sudagar M., Makhdomi N.M. 2010 - Comparison between live food and artificial diet on survival rate, growth and body chemical composition of Oncorhynchuss mykiss larvae Iran. J. Fish. Sci. 9: 19-32.
Aragăo C., Conceiçăo L.E.C., Dinis M.T., Fyhn H.J. 2004 Amino acid pools of rotifers and Artemia under different conditions: nutritional implications for fish larvae Aquaculture 234: 429-445.

Baidalinova L.S., Kryvych V.S., Balhodina L.P. 1977 - Methodological recommendations and guidelines for gas chromatography of fatty acids - Kaliningrad, Russia: AtlantNIRO, 33 p. (in Russian).

Bengtson D.A., Léger P., Sorgeloos P. 1991 - Use of Artemia as a food source for aquaculture - In: Artemia Biology (Eds) R.A. Broune, P. Sorgeloos, C.N.A. Trotman, CRC Press, Boca Raton, FL: 255-280.

Cahu C., Infante J.Z., Takeuchi T. 2003 - Nutritional components affecting skeletal development in fish larvae Aquaculture 227: 245-258.

Caraway W.T. 1959 - A stable starch substrate for the determination of amylase in serum and other body fluids Am. J. Clin. Pathol. 32: 97-99.

Chakraborty R.D., Chakraborty K., Radhakrishnan E.V. 2007 - Variation in fatty acid composition of Artemia salina nauplii enriched with microalgae and baker's yeast for use in larviculture - J. Agric. Food Chem. 55: 4043-4051.

Chepurkina M.A., Gilyeva E.A., Prusińska M., Kolman R. 2014 - The use of method of live feed enrichment in sturgeon aquaculture - V'estnik Rybohoz'aystvennoy Nauki 4: 78-90 (in Russian).

Dąbrowski K., Glogowski J. 1977 - Studies on the proteolytic enzymes of invertebrates constituting fish food Hydrobiologia 52: 171-174.

Demény F., Trenovszki M.M., Sokoray-Varga S., Hegyi A., Urbányi B., Żarski D., Ács B., Miljanović B., Specziár A., Müller T. 2012 - Relative efficiencies of Artemia nauplii, dry food and mixed food in intensive rearing of larval crucian carp (Carassius carassius) - Turk. J. Fish. Aquat. Sc. 12: 691-698.

Folch J., Lees M., Stanley G.H.S. 1957 - A simple method for the isolation and purification of total lipides from animal tissues - J. Biol. Chem. 226: 497-509.

García-Ortega A., Verreth J.A.J., Coutteau P., Segner H., Huisman E.A., Sorgeloos P. 1998 - Biochemical and enzymatic characterization of decapsulated cysts and nauplii of the brine shrimp Artemia at different developmental stages - Aquaculture 161: 501-514.

Gawlicka A., Parent B., Horn M.H., Ross N., Opstad I., Torrissen O.J. 2000 - Activity of digestive enzymes in yolk-sac larvae of Atlantic halibut (Hippoglossus hippoglossus): indication of readiness for first feeding Aquaculture 184: 303-314.

GOST 20264.2-88 1988 - Enzyme preparations. Methods for determination of proteolytic activity - Izdatelstvo standartov. Moscow, Russia, 15 p. (in Russian). 
GOST R 54058-2010 2011 - Producty pyshchevye functcionalnye. Metod opredelenyja karotynoidov Standartinform. Moscow, Russia, 8 p. (in Russian).

Hafezieh M., Kamarudin M.S., Bin Saad C.R., Abd Sattar M.K., Agh N., Hosseinpour H. 2009 - Effect of enriched Artemia urmiana on growth, survival and composition of larval Persian Sturgeon - Turk. J. Fish. Aquat. Sc. 9: 201-207.

Henderson R.J. 1996 - Fatty acid metabolism in freshwater fish with particular reference to polyunsaturated fatty acids - Arch. Anim. Nutr. 49: 5-22.

Hrytsyniak I., Smolyaninov K., Yanovich D., Vudmaska I., Yanovich V. 2009 - The biological role of $\omega$-3 polyunsaturated fatty acids and the peculiarities of their metabolism in fresh-water fish - Fishery Science of Ukraine 1: 83-87.

ISO 2002 - Animal Feeding Stuffs: Determination of Crude Ash - International Organization for Standardization ISO 5984:2002(E), Switzerland.

Kamaszewski M., Ostaszewska T., Prusińska M., Kolman R., Chojnacki M., Zabytyvskij J., Jankowska B., Kasprzak R. 2014a - Effects of Artemia sp. enrichment with essential fatty acids on functional and morphological aspects of the digestive system in Acipenser gueldenstaedtii larvae Turk. J. Fish. Aquat. Sci. 14: 1-10.

Kamaszewski M., Wójcik M., Ostaszewska T., Kolman R., Prusińska M. 2014b - The effect of essential fatty acid (EFA) enrichment of Artemia sp. nauplii on the enzymatic activity of Atlantic sturgeon (Acipenser oxyrinchus Mitchill, 1815) larvae - preliminary study - J. Appl. Ichthyol. 30: 1256-1258.

Kates M. 1973 - Techniques of lipidology. Isolation, analysis and identification of lipids - American Elsevier Pub. Co., Inc., New-York, 341 p.

Kim H., Miyazaki M., Ntambi J.M. 2002 - Dietary cholesterol oppose PUFA-mediated repression of the stearoyl-CoA desaturase-1 gene by SREBP-1 independent mechanism - J. Lipid Res. 43: 1750-1752.

Knight J.A., Anderson S., Rawles J.M. 1972 - Chemical basis of the sulfo-phospho-vanillin. Reaction for estimating total serum lipid - Clin. Chem. 18: 199-202.

Kolman R., Khudyi O., Kushniryk O., Khuda L., Prusinska M., Wiszniewski G. 2018 - Influence of temperature and Artemia enriched with $\omega-3$ PUFAs on the early ontogenesis of Atlantic sturgeon, Acipenser oxyrinchus Mitchill, 1815 - Aquac. Res. 49: 1740-1751.

Kozarenko T.D. 1975 - Ion-exchange chromatography of amino acids - Nauka, Novosibirsk, 134 p.

Lall S.P., Lewis-McCrea L.M. 2007 - Role of nutrients in skeletal metabolism and pathology in fish - an overview Aquaculture 267: 3-19.

Léger P., Bengtson D.A., Simpson K.L., Sorgeloos P. 1986 The use and nutritional value of Artemia as a food source - Oceanogr. Mar. Biol. Ann. Rev. 24: 521-623.
Lowry O.H., Rosebrough N.J., Farr A.L., Randall R.J. 1951 Protein measurement with the Folin phenol reagent - J. Biol. Chem. 193: 265-275.

McEvoy L.A., Navarro J.C., Bell J.G., Sargent J.R. 1995 Autoxidation of oil emulsions during the Artemia enrichment process - Aquaculture 134: 101-112.

Monroig O., Navarro J.C., Amat F., Gonzales P., Bermejo A., Hontoria F. 2006 - Enrichment of Artemia nauplii in essential fatty acids with different types of liposomes and their use in the rearing of gilthead sea bream (Sparus aurata) larvae - Aquaculture 251: 491-508.

Monroig O., Navarro J.C., Amat F., Gonzales P., Hontoria F. 2007 - Oxidative stability and changes in the particle size of liposomes used in the Artemia enrichment Aquaculture 266: 200-210.

Najdegerami E.H., Baruah K., Shiri A., Rekecki A., Van den Broeck W., Sorgeloos P., Boon N., Bossier P., De Schryver P. 2015 - Siberian sturgeon (Acipenser baerii) larvae fed Artemia nauplii enriched with poly-b-hydroxybutyrate (PHB): effect on growth performance, body composition, digestive enzymes, gut microbial community, gut histology and stress tests - Aquac. Res. 46: 801-812.

Navarro J.C., Henderson R.J., McEvoy L.A., Bell M.V., Amat F. 1999 - Lipid conversions during enrichment of Artemia - Aquaculture 174: 155-166.

Navarro J.C., Sargent J.R. 1992 - Behavioural differences in starving Clupea harengus L. larvae correlate with body levels of essential fatty acids - J. Fish Biol. 41: 509-513.

Nelis H.J.C.F., Lavens P., Van Steenberge M.M.Z., Sorgeloos P., Criel G.R., De Leenheer A.P. 1988 - Qualitative and quantitative changes in the carotenoids during development of the brine shrimp Artemia - J. Lipid Res. 29: 491-499.

Nguyen V.T., Satoh S., Haga Y., Fushimi H., Kotani T. 2008 Effect of zinc and manganese supplementation in Artemia on growth and vertebral deformity in red sea bream (Pagrus major) larvae - Aquaculture 285: 184-192.

Nhu V.C., Dierckens K., Nguyen T.H., Tran M.T., Sorgeloos P. 2009 - Can umbrella-stage Artemia franciscana substitute enriched rotifers for Cobia (Rachycentron canadum) fish larvae? - Aquaculture 289: 64-69.

Postel L., Fock H., Hagen W. 2000 - Biomass and abundance - In: Zooplankton Methodology Manual (Eds) R. Harris, P. Wiebe, J. Lenz, H.-R. Skjoldal, M. Huntley, ICES, London, Academic Press: 83-192.

Prusińska M., Chepurkina M., Wiszniewski G., Duda A., Kolman R. 2011 - Preliminary results of rearing larval Russian sturgeon (Acipenser gueldenstaedtii) fed enriched live feed - In: New aquaculture species. Breeding, rearing, prophylactics (Eds) Zakęś Z., Demska-Zakęś K., Kowalska A., Wyd. IRS, Olsztyn: 45-52 (in Polish). 
Prusińska M., Kushniryk O., Khudyi O., Khuda L., Kolman R. 2015 - Impact of enriching larval brine shrimp (Artemia sp.) with a supplement containing polyunsaturated fatty acids on their growth and mortality - Arch. Pol. Fish. 23: 149-154.

Sargent J.R., Bell J.G., Henderson R.J., Tocher D.R. 1995 Requirement criteria for essential fatty acids - J. Appl. Ichthyol. 11: 183-198.
Skljarov O.J., Fartushok N.V., Solskyj J., Velykij M.M., Bondarchuk T.I., Duma D. 2008 - Enzyme biochemistry. Enzyme diagnostics. Enzyme pathology. Enzyme therapy - Skljarov, Vidavnitstvo “Medicina”, Kyiv, Ukraine, 450 p. (in Ukrainian).

Tocher D. 2003 - Metabolism and functions of lipids and fatty acids in teleost fish - Rev. Fish. Sci. 11: 107-184.

Vite-García N., Simoes N., Arjona O., Mascaro M., Palacios E. 2014 - Growth and survival of Hippocampus erectus (Perry, 1810) juveniles fed on Artemia with different HUFA levels - Lat. Am. J. Aquat. Res. 42: 150-159. 